\title{
The Value and Challenges of Public Sector Information
}

\author{
Maureen Henninger \\ University of Technology, Sydney
}

\begin{abstract}
The aim of this paper is to explore the concept of public sector information (PSI), what it is, its history and evolution, what constitutes its corpus of documents and the issues and challenges it presents to society, its institutions and to those who use and manage it. The paper, by examining the literatures of the law, political science, civil society, economics and information and library science explores the inherent tensions of access to and use of PSI—pragmatism vs. idealism; openness vs. secrecy; commerce vs. altruism; property vs. commons; public good vs. private good. It focusses on open government data (OGD)—a subset of what is popularly referred to as 'big data' - its background and development since much of the current debate of its use concerns its commercial value for both the private sector and the public sector itself. In particular it looks at the information itself which, driven by technologies of networks, data mining and visualisation gives value in industrial and economic terms, and in its ability to enable new ideas and knowledge.
\end{abstract}

\section{Introduction}

Public information in all its forms pervades modern civil societies. Within liberal democracies there is the expectation that public information should be publicly available. What constitutes the corpus of public sector information (PSI); under what circumstances that corpus may or may not be made public and re-used; and the ramifications of these decisions are the focus of this paper. Public sector information in practical terms is fuzzy and often contested. It is this lack of clarity that gives rise to conflicts about access to PSI and its reuse among those generating it and other parties who wish to use it. Answers to questions concerning the ownership of public information, its economic and social values, and the kinds of rights, entitlements and privileges of individuals and particular sectors are complex, some might even say byzantine. The answers are constantly shifting, evolving and dependent on citizens' attitudes toward governmental and democratic principles.

The State, embodied in governmental institutions, is central to public information; it creates the information, often by collecting the raw data from its citizens and institutions. The State also makes use of PSI for its own decision-making and for informing the governed of those decisions. It may provide access to this information to enable its citizens' examination of government policy decisions and assessment of its governance, and to facilitate its use and 
reuse by all sectors for social and economic purposes. There is a notion that all government information belongs to its citizens because it is derived through governmental processes and therefore should be freely accessible and re-useable by them. That notion has, in part, been transformed by concepts of neo-liberalism and the commodification of information within an information society. This transformation is manifested, for example, in public-private partnerships (PPPs) where generated information may be subject to intellectual property rights, or in the private sector which frequently uses PSI for economic gain or to provide forprofit public services.

There is little dispute that public information is integral to economic development resulting in the ability to raise revenue for the delivery of social benefits which include the creation of new knowledge. Nor is it contentious in liberal democracies that public sector information is essential for the advancement of an informed citizenry which subsequently can contribute to a civil society. It is therefore, important to examine the current debates on the questions of the roles and functions of public sector information and its accessibility, and particularly on the dichotomies between self-interest and public interest, commercial value and the public good. Within the framework of these debates the paper defines public sector information and its relationship to the concept of the public domain. It then examines the role of PSI in democratic societies and the subsequent development of the open government movement and its consequences. Finally the paper explores the issues and implications of the economic and social values of public sector information, since these are ultimately the drivers of these debates.

\section{What is public sector information}

All national governments and international institutions produce information that is variously referred to as government information, government-held information and public sector information. But what it is exactly is contested (Blakemore \& Craglia 2006; Uhlir 2004). In his report for UNESCO Uhlir notes that there is 'little in official public documents or even in the scholarly literature that deals definitively with this subject' (Uhlir 2004, p. 2).

Nevertheless, at least in the context of this paper, there needs to be a comprehensive understanding of what is public sector information. This section examines the concept of PSI from the definitive perspectives of the United States, the OECD (the one accepted by Australia), and UNESCO; by discussing the issues and difficulties of each of these 
viewpoints, a working definition will be developed within which the landscape of public sector information can be explored.

In the United States the term public sector information is not widely used; rather the concept at least at the Federal level is deemed to be government information that is 'information created, collected, processed, disseminated, or disposed of by or for the Federal Government' (Office of Management and Budget (OMB) 2000). It may be argued that while this definition implies government and government-held information, such a demarcation is too narrow since it does not include all branches at all levels of government, nor does it include information created by non-government public institutions.

The OECD (Organisation for Economic Cooperation Development) definition is broader in its understanding of public sector information, however, as will be shown, it does not include some important nuances of access and use that should define public sector information. The OECD considers PSI to be 'information, including information products and services, generated, created, collected, processed, preserved, maintained, disseminated, or funded by or for the Government or public institution’ (OECD 2008, p. 4). This definition introduces two further notions that need to be considered. The first recognises a broader remit than government; that there are non-government institutions that carry out public functions, the public interest institutions - bodies governed by public law which are 'established for the specific purpose of meeting needs in the general interest, not having an industrial or commercial character' (European Commission 2003, p. 93). The second embedded notion deals with the difficulties of information produced for governments by third parties as in public-private partnerships (PPPs) and other co-operative ventures. The public sector in liberal or capitalist democracies is commonly understood to be government or political institutions whereas market institutions are within the private sector (Lane 2000, p. 1). However the boundary between the public and private sectors is neither clear nor permanent because of government privatisation, outsourcing or subsidisation of assets (services) such as prisons, hospitals and transportation (Flynn 2007). The OECD definition considers information produced in this manner to belong in the public sector.

Finally in his 2004 report for UNESCO, Paul Uhlir offers this definition of public sector information: 
information produced by public entities in all branches and at all levels be presumed to be in the public domain, unless another policy option (e.g. a legal right such as an IP right or personal privacy) is adopted and clearly documented, preventing it from being freely accessible to all (Uhlir 2004, p. 6).

If one accepts the concept that an entity is a legal fiction or institution which has legally binding rights and obligations, this definition acknowledges that PSI includes all levels and branches of government-created information. It overtly includes information produced by public institutions and recognises that there are constraints on the usage of such information, but it does not explicitly include information that is the product of public-private collaborations or contractual agreements as does that of the OECD.

On the other hand Uhlir introduces a very important concept, the public domain, which must be included in any definition of public sector information, since it has extensive legal, economic and social implications, as discussed below, for the information produced and held by governments and public institutions. Therefore for the purposes of this paper public sector information will be considered to be:

\begin{abstract}
information, including all information products in any format, and services, generated, created, collected, processed, preserved, maintained, disseminated, or funded by or for public entities (governments or public institutions) in all branches and at all levels be presumed to be in the public domain, unless another policy option (e.g. a legal right such as an IP right or personal privacy) is adopted and clearly documented, preventing it from being freely accessible to all.
\end{abstract}

\title{
The public domain
}

The idea of the public domain is deeply entrenched in western culture and the language that surrounds it connotes the notion of freedom, ipso facto, any property in the public domain is freely accessible and usable, a connotation which in the context of public sector information needs to be examined. The term arises out of an historical background of English law and the commons enclosure movements of $18^{\text {th }}$ Century England where the public domain was a matter of land rights. This concept has evolved into the contemporary notion of any property rights, including those of intellectual property being attached to creative property such as tangible information documents (Boyle 2003b). One consequence of this evolution is the present analogy of an information commons and it is argued, as we shall see, there are circumstances in which there should be access to information unfettered by property rights. While it is universally recognised that the public domain exists equally in the digital 
environment, some have argued that in the context of the Internet the domain is a virtual space, a public space or land, just like a commons (Benkler 1999; Lessig 2001).

There is an enormous amount of legislation and literature from a wide range of disciplines related to public sector information within a framework of the public domain or an information commons, much of which stems from the development of neo-liberalism and the commodification of information. In the emergent informational society and informational cities where information is a property, information generation, processing and transmission have become the fundamental sources of productivity and power (Castells 2010, p. 21, n.31) and intellectual property rights (IPR) are central to this, and indeed are the focus of much of this literature.

The legal literature examines the public domain in its historical basis and defines the modern informational public domain and commons (e.g. Boyle 2003b; Lange 1981); most agree that the 'public domain' implies material that is openly and freely accessible but with individual ownership rights (e.g. Birnhack 2006; Samuelson 2006). An interesting perspective leading to the creative commons licensing system and its application to the use of government datasets, is that 'the commons' implies material that is subject not to individual control but control by a larger group, which may impose some limits (Boyle 2003a; Rose 2003). Others (such as Boyle 2008; Samuelson 2003) contend that attaching property rights to information is comparable to an intellectual enclosure movement, a perspective that is prevalent in the informational professional literature.

Information professional scholars have been quick to apply the analogy of the commons to information (Bollier 2007; Kranich \& Schement 2008) where intellectual property rights, including copyright restrictions and extensions may prevent access to information and knowledge (Lessig 2001; Reichman \& Uhlir 2003). For example much of the opposition to new legislation (e.g. the TRIPS (Trade-Related Aspects of Intellectual Property Rights) Agreement of 1994, the WIPO Copyright Act of 1996, and the United States Digital Millennium Copyright Act of 1998) has come from the information profession, as well as from legal and economic scholars, who are concerned that public sector information will become less accessible (Benkler 1999; Perritt Jr 1997). Indeed Drahos and Braithwaite warned that TRIPS was 'the first stage in the global recognition of an investment morality that sees knowledge as a private, rather than public, good' (2003, p. 10). 
Economists have quite naturally written a great deal about the economics of information and some have examined the value of the public domain pointing out that in a knowledge economy there is both economic and social value in 'open' information (Pollock 2010; Weiss 2003). While Kirsti Nilsen (2010) in her review of economic theory and public sector information noted there had been very little specific literature on the economics of public sector information, this is changing rapidly as governments recognise that the reuse of PSI, particularly of datasets, can and does generate enormous revenues for both the public sector itself and for the private sector (Dekkers et al. 2006; Vickery 2011; Weiss 2010).

\section{The role of public sector information}

$$
\begin{array}{r}
\text { a popular Government without popular information, } \\
\text { or the means of acquiring it, is but a Prologue to a Farce or a Tragedy; } \\
\text { or perhaps both. Knowledge will forever govern ignorance: } \\
\text { a people who mean to be their own Governors, } \\
\text { must arm themselves with the power which knowledge gives } \\
\text { (James Madison) } \\
\text { genuinely public policy cannot be generated unless it be } \\
\text { informed by knowledge, and this knowledge does not exist } \\
\text { except when there is systematic, thorough, and } \\
\text { well-equipped search and record }
\end{array}
$$
(John Dewey)

The role of public sector information is mutable and multi-layered from the self-serving to the altruistic; to inform government policy decisions, to raise revenue and support economic development, to provide trust in government, to prevent government corruption, to encourage citizen participation in government, and to make knowledge available for the public good. These roles expanded and changed rapidly in the second half of the $20^{\text {th }}$ century with the development of digital technologies and electronic technologies for creating, finding, disseminating and using information.

Throughout history governments have recorded and codified information for practical, legal and administrative purposes to inform those being ruled. By example, early legal codifications such as the publically proclaimed laws of justice known as the Hammurabi Code and Solon's statutes in Archaic Greece, and administrative types of information from disparate societies, for instance those from the Neo-Assyrian empire or the Pylos archives of Mycenean Greece. Such government information generally was not for any notion of democratic processes, rather it was to serve the purposes of those in power (Tauberer 2009). Even the genesis of the United States government printing services promulgated by the 
Printing Act of 1819 was set up essentially to support legislative (congressional) activities (Stathis 1980).

However with the rise of liberal democracies in $18^{\text {th }}$ Century Europe there developed two converging ideas. The first is that democratic states have a responsibility to inform citizens of the law and therefore it follows that such information needs to be freely available; as Jeremy Bentham in his petition for codification stated 'we hear of tyrants, and those cruel ones: but, whatever we may have felt, we have never heard of any tyrant in such sort cruel, as to punish men for disobedience to laws or orders which he had kept them from the knowledge of' (Bentham 1838-1843). Secondly was the idea that governments should be held accountable to their citizens; the implication of which gave rise to the earliest freedom of information actthe Swedish Freedom of the Press Act of 1766 which 'offers greater opportunities to each of Our loyal subjects to gain improved knowledge and appreciation of a wisely ordered system of government' (Mustonen 2006).

One of the most important roles of public sector information is to serve the public interest, a fuzzy concept often used synonymously with 'public good', the meaning of which has changed across time, political regimes and democratic contexts (Box 2007; Dahl 1989; Douglass 1980; Mitnick 1976). This paper assumes the public interest is a process that balances self-interestedness particularly that of the private sector, with what can be deemed to be good for the whole of society as declared by all the people. There is an assumed understanding that, in Walter Lippmann's words 'the public interest may be presumed to be what men would choose if they saw clearly, thought rationally, acted disinterestedly and benevolently’ (Lippmann 1955, p. 42). Public interest information informs government policy decision-making to deliver benefits to society and the building of social capital; placing this information in the public domain aims to enable government accountability and transparency (Lathrop \& Ruma 2010; Longo 2011).

Finally in the era of eGovernment, eDemocracy and Government 2.0 it is apparent that governments are encouraging more citizen engagement in the democratic processes. Some scholars suggest there may be an emerging shift in these processes from a representative government to participative or direct government because of new and powerful information and communication technologies (Castells 2009; Fung \& Wright 2001). Others, however, consider this is overly optimistic and unrealistic since it may lead regulators to spend far 
more time satisfying citizen's requests to the detriment of delivering the optimal policy, under current legislation (Freedom of Information Act, see next section) that fulfils the statutory mandate or public interest (Burkert 2007). What is certain is advanced industrialised democracies governments are embracing Web 2.0 technologies to solicit citizens’ opinions and input into policy decision making (Mergel 2012) and to engage citizens in collaborative democracy (Noveck 2009). Access to public sector information for both citizens and decision makers - Cary Coglianese (2007) advises an expansion of the available information base - is an important factor for informing discussion and deliberation. As Dalton et al. note, 'citizens must have equal and effective opportunities to learn about relevant policy alternatives and their likely consequences' (2004, p. 130). The premise on which the opportunities are based is that public sector information should be open to all members of a democratic, civil society.

\section{The open government movement}

The open government movement and its implications for public sector information is a recent phenomenon representing a paradigm shift in politics and administration away from arcana imperii (literally 'secrets of empire', the term used by Tacitus to describe the secret powers and knowledge upon which autocracy rests) towards a public, new, political and administrative openness, rising from a confluence of developments in information and communication technologies, the debate over economic efficiencies of state-provided services, and public scrutiny of government secrecy (Burkert 2004; Geiger \& von Lucke 2011). One of the first formal government proclamations of this openness was that of President Obama in which he stated 'openness will strengthen our democracy and promote efficiency and effectiveness in Government' (Obama 2009). However the open government movement evolved from earlier right to information movements and their assumptions that citizens and civil societies have a right to government-held information.

It is arguable as to what kind of right this might be. James Madison and John Dewey suggested the right to read such information was implicitly essential for democracy and modern scholars generally agree (Mason 2000; Mendel 2003; Stiglitz 2003); others consider there is a legal basis to this right, including a constitutional right (Peled \& Rabin 2011; Prins 2004). It appears that the United Nations in its 1946 Resolution 59(1), considers it is a human right to 'to gather, transmit, and publish news anywhere and everywhere without fetters' and in recent years scholars are exploring the basis of access to information as an emergent human right (e.g. Birkinshaw 2006; Mendel 2003). Whatever the degree of right to 
information, the basic premise can be found in mid-20 $0^{\text {th }}$ Century legislation such as legal deposit and freedom of information acts, mechanisms to make some government documents and records public.

Legal deposit is regarded as having its genesis in a royal charter issued by King François I of France in 1537, the Ordonnance de Montpellier, which forbad the sale of any book until a copy was placed in the king's library. Most western countries now have some kind of legal deposit legislation (Jaeger, Bertot \& Shuler 2010; Larivière 2000) and most of these schemes include government and official publications such as government reports, legislative (e.g. Hansards, Congressional Records) and judicial (court and law) reports. As already noted freedom of information (FOI) began with Sweden's 1766 Freedom of Press Act but the phrase and the conditions shaping it can be traced to the second half of the $20^{\text {th }}$ Century (Burkert 2007; Relyea 1980). Currently over eighty countries now have some kind of FOI legislation and there is a range of treaties and international agreements enshrining the rights of citizens' access to government public records (Vleugels 2012). However these legislative instruments are not concerned with non-government public sector information; they enable only the reading of some but not all government-held information and certainly not the right to the reuse of its underlying data.

Open government data

So far this paper has assumed that public sector information is made up of tangible documents, i.e. products, which are the stuff of legal deposit and freedom of information legislation. However if these documents are the products of analytical processes and deliberations, it can be argued that the raw data which is created, collected and processed by governments and public institutions are also public sector information. Public access to these datasets ('big data'), driven by the open government movement and participative eGovernment and Government 2.0 initiatives that assume the data are licensed for unfettered reuse with Creative Commons type licenses, emerged as the open government data movement (OGD) in the early 2000s (Davies 2010). By 2012 Davies and Bawa (2012) suggested there were at least 100 OGD initiatives worldwide. That governments, the information industry and civil society agents recognised the potential of accurate data for the development of community services, economic growth, greater government efficiency and 
transparency and education is represented in the calls for 'raw data now' (Berners-Lee 2009; Davies 2010; European Commission 2003). The first formal initiatives and the major driver of this movement were implemented in the United States in May 2009 (Obama 2009) with its data portal project data.gov; this was followed in September 2009 by the Australian equivalent data.gov.au, by data.gov.uk (UK) in January 2010, and the EU’s opendata.europa.eu in 2012. Non-government, international public sector institutions such as the World Bank, the OECD and the United Nations followed suit.

The fast-moving environment of OGD means there is little explicit reference to or indeed description of electronic datasets in formal national and international definitions of public sector information; however they are included explicitly in various directives and legislation concerning PSI reuse either within the remit of FOI or direct access portals in the US, UK, the European Union and Australia (see e.g. Fischer 2013; Gruen 2009). The UK Protection of Freedoms Bill [Bill 146, 2011] notes a dataset 'is not the product of interpretation or analysis other than calculation (in other words that it is the 'raw' or 'source' data)'. In public sector information they are described as either 'data sets released by government in the public interest, in which all data are anonymous’ (Leadbetter 2011, p. 14), or by advocates of the information commons who regard them as 'all stored data which could be made accessible in the public interest without any restrictions on usage and distribution ... [and] combines not only stored data from the public sector, but also includes data from businesses, broadcasting stations, universities and non-profit organisations’ (Geiger \& von Lucke 2011, p. 184).

Most governments specifically exclude from reuse the datasets in the form of metadata (not the digitised objects themselves which have third-part intellectual property rights) of broadcasting stations and cultural institutions, since the metadata is costly to produce and may be a source of revenue and if freely available could pose a serious financial disadvantage (Davies et al. 2009; Quiggin 2009). However with the enormous success of the Europeana cultural heritage metadata portal (http://www.europeana.eu/portal/), the European Commission in 2011 proposed amending their Open Data Directive to include cultural institutions (Dietrich \& Pekel 2012). As well there is the issue of research data which, created through the support of government and sometimes non-government research grants, may be considered to be in the public sector. Therefore such datasets may be mandated to be made publicly available, for example the National Research Council (US), the proposed US Federal 
Research Public Access Act, the Australian Research Council, and the National Health and Medical Research Council.

The literature identifies many types of datasets, for example email (Boudrez \& Van den Eynde 2002), social media (Leadbetter 2011; Scifleet, Henninger \& Albright 2013), and statistical and scientific data including meteorological, geospatial data (Geiger \& von Lucke 2011; Pollock 2010) and research data (Arzberger et al. 2004; Borgman 2010). However the issues and challenges specific to individual types of data are not addressed in this paper.

It has been suggested that OGD is a natural evolution from freedom of information, the latest element in the FOI continuum (Halonen 2012; Heusser 2012) and, from the standpoint of the right to information and open government movements, this seems reasonable. However freedom of information legislation and open government data are not the same thing; David Eaves (2012) suggests that currently they are separate but complementary processes, with the ability of open data to circumvent the onerous and expensive processes of FOI requests while maintaining FOI's inherent protections and rights. More fundamentally OGD is a shift in the public’s attitude to public sector information, ‘in comparison to reactive freedom of information, the open-data movement—or two-way online transparency, as it is sometimes called-is seen as enabling a participative writing society instead of a reading society, where citizens are theoretically able to receive information but not to re-use it in creative ways’ (Halonen 2012, p. 22).

\section{Value of PSI data}

\footnotetext{
the true value of information is realised only when others can use and build upon it to create new ideas, inventions and strategies (Office of the Australian Information Commissioner (OAIC) 2013)
}

The number of public datasets produced by governments and public sector organisations is exploding (the Data Catalog lists 365 catalogs, the US alone containing 90,000 datasets) and the new tools and capabilities developed to support its analysis (data analytics) provide tangible and intangible value for both governments and users. While there is no intrinsic value in open data, the benefits are a result of value-added processes. In general terms governments have recognised the transformational potential of access to their own data to drive efficiency in the public sector, to provide better and new community services and basic infrastructure. There are many examples of the use of OGD to deliver weather and transport 
and environmental impact benefits, to support national and international economies, the development of technological innovations, and the contribution of new knowledge (Janssen, Charalabidis \& Zuiderwijk 2012; Wind-Cowie \& Lekhi 2012).

In economic terms, that there is enormous value in public sector datasets is summed up in a European Commission press release titled ‘Turning Government Data into Gold’ (European Commission 2011). The 'gold' can be a direct value (revenue from selling the data), a commercial value (revenue generated by companies who have purchased the data), or less quantifiable economic social benefits. Several studies have made estimations of the economic value of OGD and they are astonishing; for example the much-quoted 1990 PIRA study (2000) put the value of the EU's government datasets at $€ 68$ billion; a later study (Dekkers et al. 2006) shows it to be $€ 10$ to $€ 48$ billion, including Norway (the disparity reflects different estimation approaches). However Vickery has suggested that while aggregate direct and indirect economic impacts are worth $€ 140$ billion annually, the 'direct revenues to governments from PSI are relatively low and are much lower than the estimated benefits from access to PSI' (2011, p. 4).

The greatest value is in national and international economies where users, particularly the commercial sector, add value to the raw data along a value chain (Fornefeld et al. 2008). The PIRA study estimated the economic value of the United States to be in the vicinity of $\$ 750$ billion (this figure is for the entire information sector, not just datasets). In Australia there has not been a detailed study of the value of government datasets, however through several case studies Houghton (2011) showed that the cumulative returns far-outweighed the cost of open access supply. For example, the Australian Bureau of Statistics cost of free supply to users is $\$ 4.5$ million per annum and measurable annualised benefits of $\$ 25$ million. As a result government policies encourage high priority be given to the release of datasets with high economic and research value (e.g. Australian Government 2011; Office of Management and Budget (OMB) 2009, December 8), which in commercial terms are meteorological and geospatial data (Weiss 2010). As Dekkers et al. (2006, p. 51) note 'the fact that public bodies sell the [meteorological] data themselves clearly mirrors the value of the market'.

Advocates of open government data suggest the overriding benefits are social and political, particularly when examining the economic value delivered to society. For example, lower costs for services delivery resulting from more accurate data for decision-makers, or reliable 
meteorological data for the prediction of natural disasters (Janssen, Charalabidis \& Zuiderwijk 2012; Pollock 2011). While studies have quantified these benefits (Fornefeld et al. 2008; Weiss 2010), overall social benefits are difficult to calculate. Governments and open data supporters alike state one of the most important contributions to civil societies is government transparency and accountability (e.g. Obama 2009; Office of the Australian Information Commissioner (OAIC) 2013). This point is particularly observable with the trend in data-driven journalism, where leading newspapers such as The Guardian and the New York Times use open government datasets for investigative purposes (Cohen, Hamilton \& Turner 2011; Kronenberg 2011).

There are however some sceptical voices raising the potential dangers of public access to government datasets. Jerry Brito (2010) suggests that governments' releasing of datasets may increase accountability of those entities they regulate, but not necessarily of their own actions, while others are concerned that greater transparency expectations may be too high and that open data could, at least in the short-term, have negative effects including erosion of public trust in government (Bannister \& Connolly 2011; Bauhr, Grimes \& Harring 2010). Some scholars have warned that special interest groups - political elites, lobbyists and commercial services who use OGD - privilege those with the capacity to pay for services to the detriment of those delivered by the public sector (Baldeck 2013; Bates 2012; Kaplan 2011; Longo 2011). Finally there is always the possibility that users may misinterpret or falsely manipulate the raw data (Fioretti 2011; Halonen 2012; McGinnes \& Elandy 2012), although this concern could be expressed equally for any publicly accessible information.

Possibly the greatest value of open datasets and public sector information, in both economic and social terms, is the capacity to foster innovation and the development of new products, public services, and new knowledge emanating from pure and applied research. The proliferation of access to large datasets combined with new technological capabilities has spawned innovative projects such as the Semantic Web, the Linked Open Data project, the Internet of Things (Bizer, Heath \& Berners-Lee 2009; O’Reilly \& Bartelle 2009) and thirdparty and domain-specific applications (Anderson 2009; Pollock 2010; Salvadores et al. 2010) all of which promise extraordinary changes in ICT global connectedness.

The rapid growth of these technological innovations, the cyber infrastructure that supports data-intensive research, access to 'big data' and burgeoning R\&D investments are producing 
quantifiable results including discoveries of new health benefits (drugs, diagnoses and therapies), greater understanding of environmental health, and better capability to examine history and the social sciences (Borgman 2010; Interagency Working Group on Digital Data 2009; Uhlir \& Schröder 2007). Data analytics and new visualisation technologies are enabling pattern matching and other analytical processes to produce new knowledge in many disciplines (Fayyad, Piatetsky-Shapiro \& Smyth 1996).

\section{Conclusion}

This paper has examined the concept of public sector information and proposed a definition that includes the current notions of its inclusive nature. While a consensus on what constitutes public sector information may be reached, difficulties arise from limitations on access to its content, particularly on its reuse. Such difficulties result from historical attitudes and paradigms regarding the purpose, ownership and control of state information, from conflicting contemporary philosophies of liberal democracies and their processes, and from modern economic models for the welfare of civil societies.

States have always kept information secret both for state stability or economic interests (Pollock 2006; Roberts 2006). It has been suggested that dissemination of early codifications of public laws and administrative records, the precursors of public sector information, was not for purposes of democratisation, civil society or equality of justice, but to serve the selfinterest of the ruling powers. In liberal democracies the urge or need for secrecy still conflicts with current calls for openness and transparency in the public interest. At the institution or government level obviously there is a need for some PSI to remain secret or 'classified' for reasons of national security and defence; this paper does not argue against this general proposition. However, the withholding of public sector information often can be the result of elitist (powerful) or commercial self-interest. A case in point are documents designated ‘commercial in confidence’ (for example in public-private partnerships), or information protected from reuse by intellectual property rights. These are examples of commercial selfinterest, which nevertheless do deliver innovation and new knowledge. But with wholesale commodification of information and the rise of neo-liberalism in the second half of the $20^{\text {th }}$ century a number of scholars argue that commercial, private sector self-interest has overridden the public interest (Bates 2012; Lessig 2004; Schiller 1991). It would be wrong to suggest that the private sector is the only powerful or elitist group which benefits from access to public sector information and OGD in particular; Gurstein (2011) points out public access 
to this information may privilege the technical elites, those better able to use and analyse the data for profit or for an enriched citizen/public engagement in policy - a new data divide.

The tension between commerce and altruism in the use of open datasets, however, is nuanced. One the largest group of users is businesses that use them as test-beds for the development of innovative products or applications. While on one hand businesses are getting a 'free-ride', studies have shown that the indirect benefits are very significant, either to a country's economy or to its welfare through new public services (Davies et al. 2009; Pollock 2010; Vickery 2011). On the other hand the private use of public data to deliver services that may be better than those delivered by government, privileges the more affluent members of society; certainly there are many examples of industries such as the pharmaceutical and biotechnical industries that use public research data that delivers enormous profits to themselves to the detriment of the public good. This exploitation of public data, particularly in the areas of health and the environment, is ameliorated by government and international policies which consider the public good should override private interest (Stiglitz 1999; Uhlir \& Schröder 2007).

In the public sector itself studies have shown that the level of trust in governments is diminishing for many reasons (see e.g. Miller 1974), nevertheless there is little evidence that transparency has delivered more trust in government (Longo 2011; Worthy 2010), possibly because access to PSI enables publicity of government scandals such as the British parliamentary expenses scandal (Bowler \& Karp 2004). It remains to be seen what the longterm effects of more openly accessible public sector information and data will have on contemporary attitudes to democratic models and governments.

Finally among public sector institutions there is the conflict between pragmatism and altruism. In the words of Nat Torkington (2010):

\footnotetext{
'so while opening all data might be The Right Thing To Do from a philosophical perspective, it's going to cost money. Governments would rather identify the highvalue datasets, where great public policy comment, intra-government optimisation, citizen information, or commercial value can be unlocked' [author's emphasis].
}

Perhaps it is time to revisit national information policies that seek to balance all of these tensions among the roles and functions of public sector information, its ownership and its use. 


\section{References}

Anderson, C. 2009, Free: The future of a radical price: The Economics of Abundance and Why Zero Pricing Is Changing the Face of Business, Hyperion, New York.

Arzberger, P. et al. 2004, 'Promoting access to public research data for scientific, economic, and social development', Data Science Journal, vol. 3, pp. 135-52. http://dx.doi.org/10.2481/dsj.3.135

Australian Government 2011, Publishing Public Sector Information - Web Guide, viewed 30 May 2013, <http://webguide.gov.au/web-2-0/publishing-public-sector-information/>.

Baldeck, N. 2013, 'Opening the weather, part 2', Open Knowledge Foundation, weblog, 20 June 2013, $<$ http://blog.okfn.org/2013/06/20/opening-the-weather-part-2/ >.

Bannister, F. \& Connolly, R. 2011, 'The Trouble with Transparency: A Critical Review of Openness in e-Government', Policy \& Internet, vol. 3, no. 1, pp. 1-30. http://dx.doi.org/10.2202/19442866.1076

Bates, J. 2012, '“This is what modern deregulation looks like”: co-optation and contestation in the shaping of the UK's Open Government Data Initiative', The Journal of Community Informatics, vol. 8, no. 2.

Bauhr, M., Grimes, M. \& Harring, N. 2010, Seeing the State: The Implications of Transparency for Societal Accountability, [Working Paper Series 2010: 15], University of Gothenburg, Gotherburg, Sweden, viewed 20 May 2013, $<$ https://www.qog.pol.gu.se/digitalAssets/1350/1350160_2010_15_bauhr_grimes_harring.pdf $\geq$.

Benkler, Y. 1999, 'Free as the air to common use: First Amendment constraints on enclosure of the public domain', New York University Law Review, vol. 354, pp. 354-446. http://dx.doi.org/10.2139/ssrn.168609

Bentham, J. 1838-1843, 'Petition for Codification, 1829 [Chapter 5]', The Works of Jeremy Bentham, published under the Superintendence of his Executor, John Bowring, vol. V, William Tait, Edinburgh, p. 547.

Berners-Lee, T. 2009, The next Web of open, linked data (TED Talk), video, March 2009, $<$ http://www.youtube.com/watch?v=OM6XIICm_qo $>$.

Birkinshaw, P. 2006, 'Freedom of information and openness: Fundamental human rights?', Administrative Law Review, vol. 58, pp. 177-218.

Birnhack, M.D. 2006, 'More or Better? Shaping the public domain: Identifying the commons in information law', in L. Guibault \& P.B. Hugenholtz (eds), The public domain of information, Kluwer Law International, The Netherlands.

Bizer, C., Heath, T. \& Berners-Lee, T. 2009, 'Linked data-the story so far', International Journal on Semantic Web and Information Systems (IJSWIS), vol. 5, no. 3, pp. 1-22. http://dx.doi.org/10.4018/jswis.2009081901

Blakemore, M. \& Craglia, M. 2006, 'Access to public-sector information in Europe: Policy, rights, and obligations', The Information Society, vol. 22, no. 1, pp. 13-24. http://dx.doi.org/10.1080/01972240500388180

Bollier, D. 2007, 'The growth of the commons paradigm', in C. Hess \& E. Ostrom (eds), Understanding knowledge as a commons: , MIT Press, Cambridge, Mass., pp. 27-40.

Borgman, C.L. 2010, Research Data: Who will share what, with whom, when, and why?, [RatSWD Working Paper Series], No. 161, German Data Forum (RatSWD) Berlin

Boudrez, F. \& Van den Eynde, S. 2002, Archiving e-mail [DAVID Project], Antwerp, viewed 19 April 2013, $<$ http://www.expertisecentrumdavid.be/davidproject/teksten/Rapporten/Report4.pdf>.

Bowler, S. \& Karp, J.A. 2004, 'Politicians, scandals, and trust in government', Political Behavior, vol. 26, no. 3, pp. 271-87. http://dx.doi.org/10.1023/B:POBE.0000043456.87303.3a

Box, R.C. 2007, 'Redescribing the public interest', Social Science Journal, vol. 44, no. 4, pp. 585-98. http://dx.doi.org/10.1016/i.soscij.2007.10.006

Boyle, J. 2003a, 'Foreword: The opposite of property?', Law and Contemporary Problems, vol. 66, no. $1 / 2$, pp. 1-32.

Boyle, J. 2003b, 'The second enclosure movement and the construction of the public domain', Law and Contemporary Problems, vol. 66, no. 1/2, pp. 33-74. 
Boyle, J. 2008, The public domain: Enclosing the commons of the mind, Yale University Press, New Haven, Conn.

Brito, J. 2010, 'Panel on the future of government transparency', Sunlight Foundation, video, 29 April, viewed 20 May 2013, <http://sunlightfoundation.com/blog/2010/05/05/video-from-thetransparency-caucus-inaugural-event/>.

Burkert, H. 2004, 'The mechanics of public sector information', in G. Aichholzer \& H. Burkert (eds), Public sector information in the digital age: Between markets, public management and citizens' rights, Edward Elgar, Northhampton, Mass. , pp. 3-19.

Burkert, H. 2007, 'Freedom of information and electronic government', in V. Mayer-Schönberger \& D. Lazer (eds), Governance and information technology: From electronic government to information government, The MIT Press, Cambridge, MA, pp. 125-41.

Castells, M. 2009, Communication power, Oxford University Press, Oxford.

Castells, M. 2010, The rise of the network society: The information age: Economy, society, and culture, 2 edn, vol. 1, Wiley-Blackwell, Oxford.

Coglianese, C. 2007, 'Weak democracy, strong information: The role of information technology in the rulemaking process', in V. Mayer-Schönberger \& D. Lazer (eds), Governance and information technology: From electronic government to information government, MIT Press, Cambridge, Mass., pp. 101-22.

Cohen, S., Hamilton, J.T. \& Turner, F. 2011, 'Computational journalism', Communications of the ACM, vol. 54, no. 10, pp. 66-71. http://dx.doi.org/10.1145/2001269.2001288

Dahl, R.A. 1989, Democracy and its Critics, Yale University Press, New Haven.

Dalton, R.J., Scarrow, S.E. \& Cain, B.E. 2004, 'Advanced democracies and the new politics', Journal of Democracy, vol. 15, no. 1, pp. 124-38. http://dx.doi.org/10.1353/jod.2004.0004

Davies, R. et al. 2009, Economic and Social Impact of the Public Domain: EU Cultural Institutions and the PSI Directive [6.0 ], European Commission, viewed 3 April 2013, $<\underline{\text { http://ec.europa.eu/information_society/policy/psi/docs/pdfs/report/comm_0022_psi_v6.0.p }}$ df $>$.

Davies, T. 2010, Open data, democracy and public sector reform: A look at open government data use from data. gov. uk, viewed 30 December 2012, $<$ http://www.opendataimpacts.net/report/wp-content/uploads/2010/08/How-is-opengovernment-data-being-used-in-practice.pdf $>$.

Davies, T.G. \& Bawa, Z.A. 2012, 'The Promises and Perils of Open Government Data (OGD)', The Journal of Community Informatics, vol. 8, no. 2.

Dekkers, M. et al. 2006, Measuring European Public Sector Information Resources: Final report of study on exploitation of public sector information - benchmarking of EU framework Conditions, European Commission, viewed 30 May 2013, $<$ http://epractice.eu/files/media/media2575.pdf $>$.

Dewey, J. 2008, The Later Works of John Dewey, 1925 - 1953, vol. 2: 1925-1927, Essays, Reviews, Miscellany, and the Public and Its Problems, Southern Illinois University Press, University Park, PA., p.346.

Dietrich, D. \& Pekel, J. 2012, Open Data in Cultural Heritage Institutions, [European Public Sector Information Platform Topic Report], No. 2012 /04, $<$ http://www.scribd.com/doc/95437065/Topic-Report-Open-Data-in-Cultural-HeritageInstitutions $>$

Douglass, B. 1980, 'The common good and the public interest', Political Theory, vol. 8, no. 1, pp. 103-17.

Drahos, P. \& Braithwaite, J. 2003, Information feudalism: Who owns the knowledge economy?, New Press, New York.

Eaves, D. 2010, 'After the collapse: Open government and the future of civil service', in D. Lathrop \& L. Ruma (eds), Open government: Collaboration, transparency, and participation in practice, O'Reilly Media, Sebastopol, Calif., pp. 139-50.

Eaves, D. 2012, 'Access to Information, Open Data and the Problem with Convergence', eaves.ca, weblog, 9 March 2012, < http://eaves.ca/2012/03/09/access-to-information-open-data-andthe-problem-with-convergence/ $>$. 
European Commission 2003, 'Directive 2003/98/EC of the European Parliament and of the Council of 17 November 2003 on the Re-use of Public Sector Information', Official Journal of the European Union, vol. 345, pp. 90-6.

European Commission 2011, 'Digital agenda: Turning government data into gold', Press release, 12 December, Brussels, viewed 28 May 2013, <http://europa.eu/rapid/press-release_IP-111524 en.htm>.

Fayyad, U., Piatetsky-Shapiro, G. \& Smyth, P. 1996, 'From data mining to knowledge discovery in databases', AI magazine, vol. 17, no. 3, p. 37.

Fioretti, M. 2011, Open Data: Emerging trends, issues and best practices, Laboratory of Economics and Management of Scuola Superiore Sant'Anna, Pisa, Italy, < http://www.lem.sssup.it/WPLem/odos/odos_2.html>.

Fischer, E.A. 2013, Public Access to Data from Federally Funded Research: Provisions in OMB Circular A-110, RL30376, Congressional Research Service, Washington, DC

Flynn, N. 2007, Public sector management, 5th edn, SAGE Publications Limited, London, UK.

Fornefeld, M. et al. 2008, Assessment of the Re-use of Public Sector Information (PSI) in the Geographical information, Meteorological Information and Legal Information Sectors. Final report, MICUS Management Consulting, Düsseldorf, Germany, viewed 20 May 2013, $<$ http://www.nationalarchives.gov.uk/documents/micus report december2008.pdf $>$.

Fung, A. \& Wright, E.O. 2001, 'Deepening democracy: Innovations in empowered participatory governance', Politics \& Society, vol. 29, no. 1, pp. 5-41. http://dx.doi.org/10.1177/0032329201029001002

Geiger, C.P. \& von Lucke, J. 2011, 'Open Government Data', in P. Parycek, M.J. Kripp \& N. Edelmann (eds), Conference for E-Democracy and Open Government, Danube University Krems, Austria, pp. 183-94.

Gruen, N. 2009, Engage: Getting on with Government 2.0: Report of the Government 2.0 Taskforce, [Australian Government Information Management Office], Department of Finance and Deregulation, Canberra, viewed 12 November 2012, $<$ http://www.finance.gov.au/publications/gov20taskforcereport/doc/government20taskforcere port.pdf $>$.

Gurstein, M. 2011, 'Open data: Empowering the empowered or effective data use for everyone?', First Monday, vol. 16, no. 2, < http://firstmonday.org/ojs/index.php/fm/article/view/3316/2764 $>$.http://dx.doi.org/10.5210/fm.v16i2.3316

Halonen, A. 2012, Being open about data: Analysis of the UK open data policies and applicability of open data, The Finnish Institute in London, London, viewed 23 April 2013, $<$ http://www.finnishinstitute.org.uk/images/stories/pdf2012/being\%20open\%20about\%20data.pdf>.

Heusser, F.I. 2012, Understanding Open Government Data and addressing its Impact [draft version], viewed 12 November 2012, $<$ http://public.webfoundation.org/2012/04/ODRS/OPENDATAPAPER_DRAFT_VERSION. pdf $>$.

Houghton, J. 2011, Costs and Benefits of Data Provision: Report to the Australian National Data Service, Centre for Strategic Economic Studies, Victoria University, viewed 6 December 2012, <http://ands.org.au/resource/houghton-cost-benefit-study.pdf>.

Interagency Working Group on Digital Data 2009, Harnessing the power of digital data for science and society. Report to the Committee on Science of the National Science and Technology Council, viewed 16 April 2013, < http://www.nitrd.gov/about/Harnessing_Power Web.pdf $>$.

Jaeger, P.T., Bertot, J.C. \& Shuler, J.A. 2010, 'The Federal Depository Library Program (FDLP), academic libraries, and access to government information', The Journal of Academic Librarianship, vol. 36, no. 6, pp. 469-78. http://dx.doi.org/10.1016/j.acalib.2010.08.002

Janssen, M., Charalabidis, Y. \& Zuiderwijk, A. 2012, 'Benefits, Adoption Barriers and Myths of Open Data and Open Government', Information Systems Management, vol. 29, no. 4, pp. 258-68. http://dx.doi.org/10.1080/10580530.2012.716740

Kaplan, D. 2011, 'Open Public Data: Then What? - Part 1', Open Knowledge Foundation, weblog, January 28, 2011, < http://blog.okfn.org/2011/01/28/open-public-data-then-what-part-1/ > . 
Kranich, N. \& Schement, J.R. 2008, 'Information commons', Annual Review of Information Science and Technology, vol. 42, no. 1, pp. 546-91. http://dx.doi.org/10.1002/aris.2008.1440420119

Kronenberg, T. 2011, Data Journalism Fuelling PSI Re-Use, Topic Report No. 2011 / 2, European Public Sector Information Platform, viewed 30 October 2012, $<$ http://www.scribd.com/doc/68757562/Topic-Report-2-Data-Journalism>.

Lane, J.-E. 2000, The public sector: concepts, models and approaches, SAGE Publications Limited, London, UK.

Lange, D. 1981, 'Recognizing the public domain', Law and Contemporary Problems, vol. 44, p. 147. http://dx.doi.org/10.2307/1191227

Larivière, J. 2000, Guidelines for legal deposit legislation, CII-00/WS/7, UNESCO, Paris $<$ http://unesdoc.unesco.org/images/0012/001214/121413eo.pdf $>$.

Lathrop, D. \& Ruma, L. 2010, Open government: Collaboration, transparency, and participation in practice, O'Reilly Media.

Leadbetter, C. 2011, The civic long tail, DEMOS, London, viewed 11 May 2013, $<$ http://www.demos.co.uk/files/Civic_long_tail___web.pdf?1315915449>.

Lessig, L. 2001, The future of ideas: The fate of the commons in a connected world, Random House, New York, < http://libros.metabiblioteca.org/jspui/bitstream/001/197/8/0-375-50578-4.pdf >

Lessig, L. 2004, Free culture: How big media uses technology and the law to lock down culture and control creativity, Penguin, New York, < http://ia700702.us.archive.org/28/items/FreeCultureHowBigMediaUsesTechnologyAndTheL awToLockDownCulture 434/freeculture.pdf $>$.

Lippmann, W. 1955, Essays in the public philosophy, Little, Brown \& Co, Boston.

Longo, J. 2011, '\# Opendata: Digital-Era Governance Thoroughbred or New Public Management Trojan Horse?', Public Policy \& Governance Review, vol. 2, no. 2, p. 38.

Madison, James, 1822, 'Letter to W. T. Berry, August 4,1822', in G. Hunt (ed.), The Writings of James Madison, vol. IX, G. P. Putnam's Sons, New York and London, 1910, p. 103.

Mason, A. 2000, 'The relationship between freedom of expression and freedom of information', Freedom of expression and freedom of information. Essays in honour of Sir David Williams, Oxford University Press, Oxford, pp. 226-38.

McGinnes, S. \& Elandy, K.M. 2012, 'Unintended Behavioural Consequences of Publishing Performance Data: Is More Always Better?', The Journal of Community Informatics, vol. 8, no. 2.

Mendel, T. 2003, 'Freedom of information as an internationally protected human right', Comparative Media Law Journal, vol. 1, pp. 39-70.

Mergel, I. 2012, Social Media in the Public Sector: A Guide to Participation, Collaboration and Transparency in The Networked World, Wiley, Somerset, NJ.

Miller, A.H. 1974, 'Political issues and trust in government: 1964-1970', American Political Science Review, vol. 68, no. 03, pp. 951-72. http://dx.doi.org/10.2307/1959140.

Mitnick, B.M. 1976, 'A typology of conceptions of the public interest', Administration \& Society, vol. 8, no. 1, pp. 5-28. http://dx.doi.org/10.1177/009539977600800102

Mustonen, J. (ed.) 2006, The World's First Freedom of Information Act: Anders Chydenius' Legacy Today, Anders Chydenius Foundation, Kokkola, Sweden.

Nilsen, K. 2010, 'Economic theory as it applies to public sector information', Annual Review of Information Science and Technology, vol. 44, no. 1, pp. 419-89. http://dx.doi.org/10.1002/aris.2010.1440440117

Noveck, B.S. 2009, Wiki government: how technology can make government better, democracy stronger, and citizens more powerful, Brookings Institution Press, Washington, DC.

O’Reilly, T. \& Bartelle, J. 2009, Web Squared: Web 2.0 Five Years On. Special Report for the Web 2.0 Summit, 20-22 October, San Francisco CA, viewed 20 May 2013, $<$ http://assets.en.oreilly.com/1/event/28/web2009_websquared-whitepaper.pdf $>$.

Obama, B. 2009, Memorandum on Transparency and Open Government, viewed 6 May 2013, www.whitehouse.gov/the_press_office/Transparency_and_Open_Government/. 
OECD 2008, OECD Recommendation of the Council for Enhanced Access and More Effective Use of Public Sector Information, [C(2008)36], viewed 30 October 2012,

$<$ http://www.oecd.org/sti/44384673.pdf $>$.

Office of Management and Budget (OMB) 2000, Management of Federal Information Resources; OMB Circular A-130 Revised, $<$ http://www.whitehouse.gov/sites/default/files/omb/assets/omb/circulars/a130/a130trans4.pdf $\geq$.

Office of Management and Budget (OMB) 2009, December 8, Open Government Directive, $<$ www.whitehouse.gov/omb/assets/memoranda_2010/m10-06.pdf $>$.

Office of the Australian Information Commissioner (OAIC) 2013, Open public sector information: from principles to practice: Report on agency implementation of the principles on open public sector information, Canberra, ACT, $<$ http://apo.org.au/sites/default/files/docs/OAIC_Open_public_sector_information_from_prin ciples_to_practice_February2013.pdf $>$.

Peled, R. \& Rabin, Y. 2011, 'The constitutional right to information', Columbia Human Rights Law Review, vol. 42, no. 2.

Perritt Jr, H.H. 1997, 'Rejecting the WIPO treaties', Government Information Quarterly, vol. 14, no. 2, pp. 201-5. http://dx.doi.org/10.1016/S0740-624X(97)90020-4

PIRA International 2000, Commercial Exploitation of Europe's Public Sector Information: Executive Summary, European Commission, Directorate-General for the Information Society, Luxembourg

Pollock, R. 2006, The value of the public domain, Institute for Public Policy Research, London, viewed 23 April 2013, <http://184.107.166.173/pdf/domain.pdf $>$.

Pollock, R. 2010, 'The economics of public sector information', in B.F. Fitzgerald (ed.), Access to public sector information: law, technology and policy, vol. 1, Sydney University Press, Sydney, Australia, pp. 14-47.

Pollock, R. 2011, Welfare gains from opening up Public Sector Information in the UK, University of Cambridge, Cambridge, viewed 10 May 2013, $<$ http://rufuspollock.org/papers/psi openness gains.pdf $>$.

Prins, C. 2004, 'Access to public sector information: in need of constitutional recognition', in G. Aichholzer \& H. Burkert (eds), Public Sector Information in the Digital Age, Northhampton, Mass., Edward Elgar, pp. 48-68.

Quiggin, J. 2009, The value of Public Sector Information for Cultural Institutions: Report to Gov 2.0 Taskforce, viewed 16 April 2013, <http://gov2.net.au/projects/project-6/>.

Reichman, J.H. \& Uhlir, P.F. 2003, 'A contractually reconstructed research commons for scientific data in a highly protectionist intellectual property environment', Law and Contemporary Problems, vol. 66, no. 1/2, pp. 315-462.

Relyea, H.C. 1980, 'Freedom of information and government printing', Government Publications Review. Part A, vol. 7, no. 5, pp. 407-15. http://dx.doi.org/10.1016/0196-335X(80)90073-4

Roberts, A.S. 2006, Blacked out: Government secrecy in the information age, Cambridge University Press, New York.

Rose, C.M. 2003, 'Romans, roads, and romantic creators: Traditions of public property in the information age', Law and Contemporary Problems, vol. 66, no. 1/2, pp. 89-110.

Salvadores, M. et al. 2010, 'Domain-specific backlinking services in the web of data', paper presented to the IEEE/WIC/ACM International Conference, Web Intelligence, 2010.

Samuelson, P. 2003, 'Mapping the digital public domain: Threats and opportunities', Law and Contemporary Problems, vol. 66, no. 1/2, pp. 147-71.

Samuelson, P. 2006, 'Enriching discourse on public domains', Duke Law Journal, vol. 55, no. 4, pp. 789-91.

Schiller, H.I. 1991, 'Public Information Goes Corporate', Library Journal, vol. 116, no. 16, pp. 42-5.

Scifleet, P., Henninger, M. \& Albright, K. 2013, 'When social media is your source', paper presented to the International Conference on Conceptions of Library and Information Science (CoLIS 8), August 19-22, Copenhagen, Denmark. 
Stathis, S.W. 1980, 'The evolution of government printing and publishing in America', Government Publications Review. Part A, vol. 7, no. 5, pp. 377-90. http://dx.doi.org/10.1016/0196$\underline{335 \times(80) 90070-9}$

Stiglitz, J.E. 1999, 'Knowledge as a global public good', in I. Kaul, I. Grunberg \& M. Stern (eds), Global public goods: International cooperation in the 21st century, Oxford University Press, New York, pp. 308-26.

Stiglitz, J.E. 2003, 'On liberty, the right to know, and public discourse: The role of transparency in public life', in M.J. Gibney (ed.), Globalizing Rights: The Oxford Amnesty Lectures 1999, Oxford University Press, Oxford, UK, pp. 115-60.

Tauberer, J. 2009, 'Open Government Data: An Information Goldmine, Open To All', e-government Bulletin, weblog, September 4th, 2009, Headstar Publications, < http://www.headstar.com/egblive/?p=251 >.

Torkington, N. 2010, 'Rethinking Open Data: Lessons learned from the Open Data front lines', O'Reilly Radar, weblog, February 2, 2010, < http://radar.oreilly.com/2010/02/rethinkingopen-data.html >.

Uhlir, P.F. 2004, Policy Guidelines for the Development and Promotion of Governmental Public Domain Information, CI-2004/WS, UNESCO, Paris, viewed 30 October 2012, $<$ http://unesdoc.unesco.org/images/0013/001373/137363eo.pdf $>$.

Uhlir, P.F. \& Schröder, P. 2007, 'Open data for global science', Data Science Journal, vol. 6, pp. 3653. http://dx.doi.org/10.2481/dsj.6.0D36

Vickery, G. 2011, Review of recent studies on PSI re-use and related market developments, viewed 30 October 2012, $<\underline{\text { http://www.umic.pt/images/stories/publicacoes6/psi_final_version_formatted-1.pdf }>\text {. }}$

Vleugels, R. 2012, 'Fringe Special: Overview of all FOI laws', 30 September 2012, viewed 23 April 2013, < http://www.statewatch.org/news/2010/sep/foia-fringe-special-overview-sep-202010.pdf $>$.

Weiss, P. 2003, 'Conflicting international public sector information policies and their effects on the public domain and the economy', in J.M. Esanu \& P.F. Uhlir (eds), The Role of Scientific and Technical Data and Information in the Public Domain: Proceedings of a Symposium, National Academic Press, Washington D.C., pp. 129-32.

Weiss, P. 2010, 'Borders in cyberspace: Conflicting public sector information policies and the economic impacts', in B. Fitzgerald, et al. (eds), Access to Public Sector Information: Law, Technology and Policy, vol. 2, pp. 592-608.

Wind-Cowie, M. \& Lekhi, R. 2012, The data dividend, DEMOS, London, viewed 11 November 2012, $<$ http://www.demos.co.uk/files/The_Data_Dividend_-_web.pdf $>$.

Worthy, B. 2010, 'More open but not more trusted? The effect of the Freedom of Information Act 2000 on the United Kingdom central government', Governance, vol. 23, no. 4, pp. 561-82. http://dx.doi.org/10.1111/j.1468-0491.2010.01498.x 